\title{
Strategies and Innovations in Modern Trade Marketing
}

Submitted 21/01/19, 1st revision 29/03/19, 2nd revision 06/05/19, accepted 16/06/19

\author{
Diyanova S.N. ${ }^{1}$, Guba E.N. ${ }^{2}$, Guseva M.V. ${ }^{3}$, Popova T.S. ${ }^{4}$
}

\begin{abstract}
:
Purpose: The article is devoted to the critical analysis of existing theoretical and methodological approaches to determining the content and nature of sales marketing as a factor and element of companies' competitive strategy.

Design/Methodology/Approach: Based on a critical retrospective analysis, authors presented the features of the trade marketing toolkit providing substantial increase in market sales. Authors considered key existing functional marketing strategies, as well as its innovative trends and ideas.

Findings: The modern market of trade enterprises is characterized by fundamental changes in economic conditions caused by the transformation of the economic system, the market priority of consumers, the formation of the information society, and the integration of economic processes. The economic phenomena escalate the struggle in the trading business for its share of the competitive market. In order to maintain and strengthen their positions, trade enterprises should build their trade and technological processes more and more efficiently.
\end{abstract}

Practical implications: Economic growth of a commercial enterprise could be carried out in line with intensive and extensive factors. With the growing level of concentration of the trade industry, factors of intensive economic growth of trade enterprises become relevant.

Originality/Value: The author's approach could be used in the development of promising corporate marketing strategies in terms of the development and implementation of innovative marketing solutions available for implementation throughout the entire cycle of the strategic marketing process.

Keywords: Trade marketing, complex marketing in sales, innovation in trade.

JEL Codes: D10, D11, D12, D30, D39.

Paper Type: Research article in a Special Issue dedicated to Russian Economy.

Section 8: Business and Economic Issues.

${ }^{I}$ Ph.D. in Economics, head of the Chair of trade and catering, Plekhanov university of economics, Krasnodar branch, Krasnodar, Russian Federation, dianova@mail.ru ${ }^{2}$ Ph.D in Technology, Associate Professor, Department of Trade and Catering, Plekhanov university of economics, Krasnodar branch, Krasnodar, Russian Federation, guba@mail.ru ${ }^{3}$ Ph.D in Technology, Associate Professor, Department of Trade and Catering, Plekhanov university of economics, Krasnodar branch, Krasnodar, guseva@mail.ru

${ }^{4}$ Ph.D. in Economics, Associate Professor, Department of Marketing and Trade, Kuban State University, Krasnodar, Russian Federation, tanya930@ rambler.ru 


\section{Introduction}

In modern market conditions with its ultra-high competition in almost all segment, any manufacturer striving to operate successfully must certainly focus on the quality and relevance of the products. Without quality products, any business is destined to failure. But the quality of the product or its timely delivery to the consumer are not the only concern of the business. Methods of promotion of products, their recognition are very important in the modern market as well. It is the task that trade marketing resolves. Therefore, the strategy and tools of trade marketing have recently become increasingly relevant.

\section{Background of the Trade Marketing Concept}

A certain economic success of trade organizations in the modern economy led to the strive to imitate the prevailing stereotype of business management in economies of transitional and catching-up types. The very economic growth and success in business activity of firms, as a rule, is in a certain connection with the development of marketing. But catching-up economies, copying advanced and successful variants of market behavior aimed at the customer within the framework of trade marketing, are forced to move away from samples taken as a reference because of the discrepancy between local economic realities and reference economies. The discrepancies lie, first, in a different resource supply, lower overall effective demand and the attitude of the population to the quality and quantity of services provided related to trading and marketing activities.

Japan is considered the birthplace of trade marketing. In Tokyo in 1690, Mitsui opened the first department store. This store had a trade policy that was about 250 years ahead of its time. For the first time in the history of marketing, the shopkeeper focused more on his customers, buying only what was needed, providing a guarantee system for the quality of the goods, placing the goods on the shelves systematically, constantly expanding the range of goods (Brizhasheva, 2007).

In Russia, domestic entrepreneurs (the merchants) successfully used sales and staff promotion techniques. In Russia, it has always been customary to drive the buyer with the help of simple trade marketing methods. For example, it was customary to let the customers buy good-measure goods (add extra goods for the same price), provide goods for testing, deliver goods purchased, etc., (Brizhasheva, 2007).

At the end of the 19th century, with the emerging of self-service retail, department stores, with the goal of selling goods from the shelves, the first organized campaigns of trade marketing to drive the sales were organized. Trade marketing was applied situationally basing on understanding of the current problem; therefore, trade marketing activities were included in the advertising budget of companies. At the time, trade was given less attention than advertising (Valeeva and Martynova, 2013). 
At the beginning of the 20th century in Belgium and in France, shopping centers started to open on the outskirts of cities. The consumer traffic there became more important than the profitability per unit of goods. A greater number of buyers and purchases were provided with stocks and promotions, which buyers learned from advertisements delivered to their homes. Low prices, great deals, and all sorts of different trading tricks - such arguments forced the buyer to go to retail outlets. In 1916, the first self-service store opened in the USA. Americans also invented the formats of a shopping center (1922-1923) and a hypermarket (supercenter) (1930), promoting the development of trade marketing (Brizhasheva, 2007).

In the 20th century, another trade marketing area was formed - sales staff promotion. In order to bind their sellers, turn them to the business of the firm and make them feel "the spirit", the companies began to resort to the following methods of trade marketing: financial incentives, competitions among sellers, and payments of bonus rewards. All of them are sales marketing tools to stimulate sales staff (McDonalds is considered a pioneer in this area) (Shpakova, 2011).

At the turn of the 20th and 21st centuries, the ratio between the cost of advertising and trade marketing in all market segments already averaged $60 \%$ to $40 \%$ in favor of advertising. Over the past ten years of the 20th century, trade marketing has been recognized as an independent marketing tool. At the same time, in several segments, trade marketing, is used as an independent tool to a greater extent than other marketing tools like PR, advertising, direct marketing.

In Russia, at the turn of the century, trade marketing was spoken about only within the framework of the general concept of creating and promoting demand without isolating any kind of promotional marketing activities. The most popular is still the only one "hard" tool of sales marketing - the provision of a discount (Trade marketing. New product promotion, 2017).

Since the beginning of the 21 st century, there has been an active growth in the services of trade marketing. Modern technologies are rapidly changing our lives. Today, we are no longer surprised by refrigerators, self-ordering products or cameras, instantly saving captured images in the cloud. Technological progress has affected all areas of consumer life: it has changed the product we consume, the processes of its choice and purchase, and, of course, the place where this purchase takes place. When things change so quickly, it is important for modern trade marketers not only to respond to the changes, but also to foresee their vector.

\section{The Nature, Purpose and Goals of Trade Marketing}

Trade marketing is a set of measures designed to establish more productive interaction with all participants in the sales process, from the manufacturer of the product to its buyer. Trade marketing allows implementing the existing product and provides an 
opportunity to inform customers about the company's offer in the most natural way for them (Trade marketing. New product promotion, 2017). Trade marketing is a marketing direction that allows increasing the number of sales by improving and optimizing the distribution chain. The product chain includes all links for product sales (manufacturer, distributor, point of sale, sales team). The specificity of trade marketing allows you to create an effective link between all parts of the marketing chain with the help of both organizational measures and promoting factors of participants in the process.

Trade marketing cannot exist outside the other components of the marketing mix. Using trade marketing, the following goals are achieved: an increase in sales of the company's products through the application of trade marketing tools; increasing brand awareness among customers; achieving a stable position of the brand in the market; increasing brand loyalty among the target audience; elimination of obstacles to the passage of goods in the marketing channel and promotion of sales of goods; increase in the number of buyers; an increase in the quantity of goods purchased by the same buyer.

The purpose of trading marketers include such classic marketing tasks as: analyzing the situation on the market in terms of analytics of the activities of resellers; increasing brand distribution in all sales channels; creating a trademark domination effect in the sales channel over competitors; the formation of the consumer's positive brand image; organization of promo-events; control over their implementation and evaluation of their effectiveness; analysis of competitors; analysis of the effectiveness of the distribution network; maintaining a distribution network with sales marketing tools; work with the staff of distributors and retailers, etc. (Trade marketing: New product promotion, 2017).

\section{Key Trade Marketing Strategies}

Trade marketing strategies are often the part of overall marketing strategy of a business and are designed to successfully complement it. They are directed, above all, to obtain maximum economic results - increasing sales and business profitability. At the same time, the strategies themselves should be as cost effective as possible, using limited financial resources to achieve the goals.

Functionally, trade marketing strategies could have several main areas.

1) Strategies for interacting with all representatives of the commodity chain. The main goal of these strategies is to establish and ensure reliable operation of all links in the distribution chain from the manufacturer to the final consumer.

2) Strategies for cooperation with the consumer, with the target audience. They are an important component of trade marketing. They include the development of various promotions, lotteries, auctions, discount systems, etc. 
3) Merchandising strategies. Their basis is the development of recommendations for the presentation of products at each stage of implementation. The practical significance of these strategies lies in the competent formulation of the optimal range of products, considering their individual qualities.

These strategies allow choosing the right place of the product in the sales point and form the minimum necessary stocks of products. Merchandising strategy allows solving the following problems: determining the priority, main and additional items of the goods; determining how many items should include the range of each outlet; determining the place in the sales channel for a specific product (product category, placement area in the category, additional points of sale); formation of the minimum required stock for each item of the goods. The strategy of trade marketing is considered correct only in the case when the use of all its components leads to a real increase in sales volumes and an increase in profits.

Developing a trade marketing strategy includes the following steps: market research; analysis of its condition; competitor analysis and evaluation of the company itself; setting marketing strategy objectives; consumer interest research; positioning development; economic analysis strategy. Effective trade marketing strategy could be considered the one that brings extra sales and profits.

\section{Main Trade Marketing Tools}

The trade marketing toolkit is very broad. Constantly, new tools of trade marketing are emerging. This is due primarily to the constant emergence of new technical capabilities. The most common tools for trade marketing include:

1. Motivation of sellers. Most often the manufacturer does not have the ability to communicate with representatives of their target audience directly but does so exclusively through intermediaries or sellers. And sales promotion has a significant role in successful sales. The salesman's incentive method is based on their motivation with the help of bonuses, gifts, rewards for fulfilling the sales plan, which helps increase sales or bring new products to the market.

2. Work with resellers. This is to support the participants of the intermediary commodity distribution chain. The support and promotion is usually carried out by the supplier of products and is organized in the form of various actions that are aimed at increasing the volume of purchases.

3. Organization of exhibitions and product presentations.

4. Organization of trainings for resellers. Training resellers and direct participants in the process of marketing products is very important. Trained staff sells many times more and, in addition, significantly increases the loyalty of customers to the brand. 
5. Using POS materials.

6. Motivation of the end-customer. A great variety of tools and methods for end-user rewards, for example, gifts when buying, prize draws, additional coupons, etc. This question is rather broad.

7. Business meetings and conferences. Periodic meetings of the representatives of the supplier and the most important resellers at which the results are summarized, further prospects for cooperation are discussed, problems are identified, and solutions are discussed.

8. Using indoor advertising. It is usually located in places with high traffic like shopping centers, entertainment centers, supermarkets, airports, etc.

9. Using an effective advertising campaign. For a product to meet as many potential consumers as possible, except for internal advertising, it is necessary to use all available types and methods of advertising so that it, at minimum financial cost, contributes to an increase in the customer base. These can be traditional forms of advertising like print, radio, billboards, internet, etc.

\section{Innovative Approaches to the Development of Trade Marketing}

The modern market of trade enterprises is characterized by fundamental changes in the economic conditions caused by transformation of the economic system, market priority of consumers, formation of the information society, and integration of economic processes. The processes occurring in the economy, escalate the struggle in the trading business for its share of the competitive market. In order to maintain and strengthen their positions, trade enterprises should build their trade and technological processes more and more efficiently.

Of course, modern technologies form the future of retail. In many ways, it will be associated with the development of a mobile economy and big data. Progress in retail will be provided by the understanding of each particular consumer and his desires. Based on fiscal information, retailers will be able to create personalized messages, target the audience, study and build a range depending on the information collected.

The main trend of innovation activity in marketing is the automation of all marketing tools. This is typical both for agencies and for advertisers themselves, who started active development of inhouse advertising tools, including programmatic buying, DM-platforms, SMM, email-marketing, to save budgets for agency services without expanding their own staff.

We believe that in 2019, when planning advertising campaigns, brands will increasingly pay attention to customer experience and finally move to omnichannel communications with consumers. The integration of digital and traditional marketing 
tools will continue. The development of the necessary technological solutions for this (connected with augmented reality, face recognition, etc.) requires huge investments, so large companies will take it. As soon as the technological base is created, small developers will come and generate content on ready-made platforms.

\section{Conclusion}

Speaking of trade marketing, we note that this is just one of the ways to promote sales of products, one of their types of marketing. But it is an integral part of the overall marketing plan of the business, and should be carried out in close connection with other marketing programs to promote products and develop the business as a whole.

The decision on the use of certain tools of trade marketing is made for themselves by each specific business. The use of each of the tools is determined primarily by the characteristics of the specific situation and business opportunities. It is very important to determine exactly those strategies and tools that at the minimum cost will bring the desired result.

Economic growth of a commercial enterprise can be carried out due to intensive and extensive factors. With the growing level of concentration of the trade industry, factors of intensive economic growth of trade enterprises become relevant. Innovations as a factor of intensive economic growth are reflected in the indicators of intensive development of trade enterprises.

\section{References:}

Brizhasheva, O.V. 2007. Trade marketing. Ulyanovsk, ULSTU publ., 170.

Shpakova, A.V. 2011. An Innovative Factor for the Sustainable Development of Trade Enterprises. Ph.D. thesis abstract, Bryansk.

Trade marketing. Promotion of a new product, 2017. Available at: https://malbusiness.com/treyd-marketing-prodvizhenie-novogo-produkta-na-ryinok/

Valeeva, Yu.S., Martynova, O.V. 2013. The economic content of the intensive development of retail distribution services. Kazan Cooperative Institute (branch) of the Russian University of Cooperation, 5, 87-91. 